\title{
A Progress Report
}

to

Division of Biology and Medicine

U. S. Atomic Energy Commission

Washington, D. C.

STUDIES ON VIRUS-INDUCED CELL FUSION

Contract No. AT $(11-1)-3419$

Period covered: August 1, 1973 - July 31; 1974

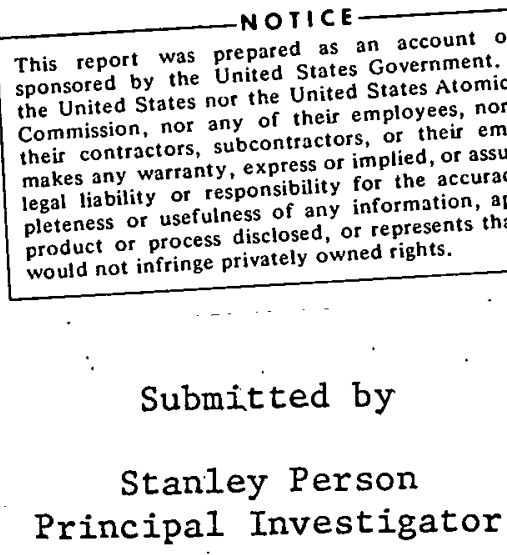

Biophysics Department

College of Science

The Pennsylvania State University

University Park, Pennsylvania 16802 


\section{DISCLAIMER}

This report was prepared as an account of work sponsored by an agency of the United States Government. Neither the United States Government nor any agency Thereof, nor any of their employees, makes any warranty, express or implied, or assumes any legal liability or responsibility for the accuracy, completeness, or usefulness of any information, apparatus, product, or process disclosed, or represents that its use would not infringe privately owned rights. Reference herein to any specific commercial product, process, or service by trade name, trademark, manufacturer, or otherwise does not necessarily constitute or imply its endorsement, recommendation, or favoring by the United States Government or any agency thereof. The views and opinions of authors expressed herein do not necessarily state or reflect those of the United States Government or any agency thereof. 


\section{DISCLAIMER}

Portions of this document may be illegible in electronic image products. Images are produced from the best available original document. 
Progress Report

During the past year our research effort has been divided between biological effects produced by tritium decay and on virus-induced cell fusion. Frank Krasin, who finished his Ph.D. degree in June, 1973, continued working in my laboratory during the summer in an attempt to complete our work on tritium decay. As a result of his efforts our work on tritium decay in microorganisms is essentially completed. We now have examined all of the non-exchangeable $\mathrm{H}$-atom positions in nucleic acid purines and pyrimidines that are susceptible to labeling with tritium. We assayed the lethality and mutation production in bacteria and changes in the primary structure of bacterial DNA stored in vitro (for example, alkali-labile strand breaks and cross-links). The H-positions that can be labeled with tritium are the 5,6positions of pyrimidines and the 8-position of purines and the 2-position of adenine. The goal was to determine if effects other than those ascribed to $\beta$-particle ionization could be detected. In other words, are there local effects or transmutation effects produced by decays? Our experiments always involved comparing effects/decay for decays originating from two different atoms in the same pyrimidine. For example, in one experiment we would determine the mutations produced/decay by cytosine-6- ${ }^{3} \mathrm{H}$ decays and in another experiment we would determine the mutations produced/decay by cytosine-5- ${ }^{3} \mathrm{H}$ decays. Our conclusions are as follows.

We have discovered three major transmutation effects: ( 1 ) Decays from cytosine-5- ${ }^{3} \mathrm{H}$ produce an alteration of the previously labeled cytosine molecule so that either uracil is produced (Krasin, Ph.D. Thesis) or a molecule that codes as uracil during DNA replication (Osborn, Person, Phillips and Funk, 1967) and is converted to uracil during chemical breakdown of DNA. 
The efficiency of this process appears to be about 0.35 or occurs in one decay in three. (2) Decays from adenosine-2- ${ }^{3} \mathrm{H}$ produce cross-1inking of DNA in vitro with an efficiency that appears to be nearly $100 \%$. That is, nearly every decay results in cross-linking. Decays from other labeled positions do not show this tendency. Alkaline sucrose gradients of stored DNA labeled with adenosine-2- ${ }^{3} \mathrm{H}$ show a peak that sediments more rapidly than the starting material. The magnitude of this peak increases with storage time of the DNA. It is interesting that this is the only tritium-labeled molecule that contains a label facing toward the complementary DNA strand. All other labeled positions are on the outside of the DNA helix. This result was our major discovery of last summer and is currently being prepared for publication. (3) Decays from cytosine- $6-{ }^{3} \mathrm{H}$ (and apparently from thymidine-6- ${ }^{3} \mathrm{H}$ ) produce alkali-labile strand breaks in bacterial DNA in vitro with an efficiency of 37\% (Krasin, Person and Snipes, 1973): The DNA was stored frozen in low concentrations to minimize radiation damage from decays originating in neighboring DNA molecules. By comparison, decays originating in cytosine-5- ${ }^{3} \mathrm{H}$ and guanosine-8 $-{ }^{3} \mathrm{H}$ produce strand breaks with an efficiency: of $7-9 \%$ per decay. With regard to lethality, all of our data may be explainable on the basis of radiation damage to cellular DNA. This means that the single-strand breaks produced by cytosine- $6-{ }^{3} \mathrm{H}$ decays are efficiently repaired as are the crosslinks produced by adenosine-2- ${ }^{3} \mathrm{H}$ decays. If there is a transmutation effect for tritium decays originating from any of these labeled molecules it is quite small. We reserve judgment on the decays from adenosine-2- ${ }^{3} \mathrm{H}$ until radiation-sensitive mutants have been examined, but for the bacteria we have studied there is no evidence for a significant transmutation effect for lethality. 
In addition to the above, minor transmutation effects for mutation production have now been observed for adenosine-2- ${ }^{3} \mathrm{H}$ decays (about $3 \%$ efficiency) and for thymidine-6- ${ }^{3} \mathrm{H}$ decays (less than $1 \%$ ).

In our studies of virus-induced cell fusion caused by mutants of HSV we have isolated about 20 such mutants and we are beginning to characterize these. One experiment that we have proposed was to determine if mutant virus infection merely causes the expression of pre-existing host genes that cause cell fusion. This has been investigated to date by inactivating host RNA and protein synthesis activity by UV prior to virus infection and determining the residual host syntheses at times corresponding to the time of appearance of cell fusion in infected cells. In separate experiments we determined the effect of UV on fusion ability. The data are given in Appendix 2 and indicate that expression of host genes during virus infection probably does not cause cell fusion.

Data for all the above are shown in the appendices.

\section{Bibliography}

T. Krasin, Physical and chemical studies of cytosine-5- ${ }^{3} \mathrm{H}$ decay and cytosine-6$3_{\mathrm{H}}$ decay occurring in bacterial DNA. Ph.D. dissertation, The Pennsylvania State University, 1973.

M. Osborn, S. Person, S. L. Phililips and F. Funk, Determination of mutagen specificity in bacteria using nonsense mutants of bacteriophage T4. J. Mol. Biol. 26:437-447 (1967).

F. Krasin, S. Person and W. Snipes, DNA strand breaks from tritium decay: a local effect for cytosine-6-3H. Int. J. Radiat. Biol. 23:417-420 (1973).

PUBLICATIONS RESULTING FROM THE PROJECT:

F. Krasin, S. Person and W. Snipes (above; previously submitted as page proofs, co0-3419-7)

S. Person, J. McCloskey, W. Snipes and R. C. Bockrath, Ultraviolet mutagenesis and its repair in an $\underline{E}$. coli strain containing a nonsense codon. Submitted for publication. (Previously submitted as preprint, $000-3419-5$ ).

F. Krasin, R. Ley and S. Person, DNA cross-links from tritium decay: a local effect for adenosine-2-3 $\mathrm{H}$ (manuscript in preparation). 
Related Research:

A. D. Keith, R. Morse, M. Ruhlig and W. Snipes. Viscosity profiles of sarcoplasmic reticular vesicles (manuscript in preparation; M. Ruhlig is a graduate assistant supported by this grant).

PERSONNEL ON THE PROJECT:

S. Person, Principal Investigator

T. Holland, Graduate assistant

M. Ruhlig, Graduate assistant 